\title{
Discussion on the Trend of China's Commercial Banks Management: Based on the Influence of Financial Market Development
}

\author{
Miaomiao Lv \\ Jinan University, Guangzhou, China \\ Email: Ivmiaomiao691@163.com
}

Received 21 June 2016; accepted 19 July 2016; published 22 July 2016

Copyright (C) 2016 by author and Scientific Research Publishing Inc.

This work is licensed under the Creative Commons Attribution International License (CC BY). http://creativecommons.org/licenses/by/4.0/

c) (i) Open Access

\begin{abstract}
As the environment of commercial banks, the development of financial market has a profound impact on the commercial banks. In recent years, the continuous development of financial market is both an opportunity and a challenge for the commercial banking industry. This paper tries to analyze commercial bank business challenges brought about by the development of the financial market mainly from three aspects: the development of Internet banking rise, interest rates liberalization and deposit insurance system, financial industry mixed operation trend and takes it as a starting point to explore the trend of development of commercial bank management from the commercial bank organization structure, management mode and business development three aspects.
\end{abstract}

\section{Keywords}

Financial Market, Commercial Bank Management, Opportunity, Challenge

\section{Introduction}

In recent years, the domestic financial market system is constantly advancing and improving, the role of financial market allocation of resources is increasing, which makes the influence on the domestic economic and financial significantly enhanced. From the perspective of the banking sector, the current financial market development presents the following basic characteristics. 


\subsection{The Rise of Internet Banking}

June 13, 2013 was a memorable day in the history of finance. On this day, the balance of treasure that was called value-added services jointly built by Alipay and Celestica fund balance and began gradually into the public eye [1]. In just a few months, represented by its various kinds of Internet financial products has made the traditional banking showed on pins and needles. Subsequently, the third party payment, network lending, the public to raise financing as the representative of the Internet developed as speed of far more than the imagination of people.

\subsection{Interest Rate Liberalization and the Development of Deposit Insurance System}

In the deposit, interest rates went up 10\% only a year later, in July 2013, China canceled the loan interest rate control, and in November 2014 the deposit rate cap further expanded to 20\%, The last two years, the interest rate market reform suddenly speeded up. The people's Bank of China has done a good job in the preparation of technical and conditions, the market rate of deposit can be realized as soon as possible Zhou (2013). Particularly the Third Plenary Session of the 18th Central Committee of the Communist Party of China will further clear the principle of reform to promote the steady progress of the interest rate market as to accelerate the interest rate market reform requirements. Although the interest rate market will have a profound impact on the steady growth of China's economy and the adjustment of economic structure Jin (2013), but international experience also shows that the interest rate market competition after the opening of the financial sector may also bring a certain impact on the smooth operation of the financial sector (Liu 2013).

Moreover, in the framework of the reform of the interest rate market, the deposit insurance system is introduced. After the liberalization of deposit interest rates, bank competition for deposits will raise the cost of deposit taking banks, small banks, if poorly managed, may face the risk of bankruptcy, then you need the deposit insurance system to protect the depositor's interests. Since the deposit insurance system was implemented in May 1, 2015, China has become the 114th country to establish a deposit insurance system in the world.

\subsection{The Trend of Financial Mixed Operation Is Constantly Emerging}

At present, according to the commercial bank law, the Chinese commercial banks are still unable to engage in securities, insurance, trust and other business operations. But relevant institutions explicitly recognized the financial holding company model in 2012, they declared: continue to actively and steadily push forward the pilot of the financial comprehensive operation and guide have qualified financial institutions actively and steadily carry out the comprehensive management pilot, improve the comprehensive financial service ability and the level under the premise that clear the strategy of comprehensive management, guard against the risk effectively [2]. To guide the pilot financial institutions according to their own risk management and control capabilities and comparative advantage to select the financial industry comprehensive business model and promote the development of the Citic Group Inc and China Everbright Group to deepen reform, into a truly standardized financial holding company. This means that the development of the financial holding company model has been supported by the national policy and training, at the same time, it provides an alternative path for commercial banks to carry out mixed operation. This shows that the commercial banks in the future will be more policy support.

\section{The Rapid Development of Financial Market, Opportunities and Challenges}

Commercial bank as a financial intermediary, its advantage is that it can use technology to reduce the size of the economic transaction costs. But with the progress of the transaction technology and the continuous improvement of the Internet technology, the cost will be reduced by the incomplete information, financial intermediation advantage in lowering specific cost no longer exist, obviously, Internet banking has gradually involved in the traditional core business of the bank and bring a threat to the operation and management of commercial banks. The main impact in the following aspects.

\subsection{The Role of Financial Intermediary in Commercial Banks Is Gradually Weakening}

The development of network technology makes it easy to collect information, and also reduce the cost of the transaction. Thus reducing the demand for commercial banks to finance intermediary services. In the traditional financing process, a great obstacle is the supply and demand of funds to communicate the information of the 
supply and demand of funds in real time [3]. As the main financial intermediaries in a daily economic life, the commercial bank is distributing center of commercial activities in the capital supply and demand information, and in the long-term practice of management, formed as one of the economies of scale including a set of information collection, information processing, etc. However, due to the rapid development of network technology, information transmission and mode of transmission occurred huge change, which provides substantial information for financial transactions, thus forming no longer with the bank's financial transfer.

The establishment of commercial bank payment intermediary status is based on the time and space of the funds supply and demand of the two sides is not unified. But Internet based information technology-Internet banking can break the restrictions of time and space, only from this point, it can be a great threat to the traditional commercial banks in the payment process of the central position.

Online sales of financial products, which threaten the status of traditional bank sales channels. Under the supervision of the regulatory authorities, the sales of financial products can be covered all over the country, which to a certain extent, expand the sales of financial products. But, banks want to sell financial products must be with the business network, which greatly limits the development of commercial bank financing business.

\subsection{The Source of Income of Commercial Banks Is Impacted}

Net lending affects the spread income of commercial banks, network lending by virtue of the more extensive coverage in the ordinary individual customers than the traditional financial institutions and to raise funds for the enterprise, so as to develop quickly. Thus form an effective competition with traditional banks in the personal and small, micro business lending areas. And with the further application of the network, the big companies will also join the camp to the Internet lending, then, the traditional banking where to go from here.

Third party payment services are being swallowed up the development of traditional banks in the intermediary business. Currently, a number of companies have a great interest in the development of new business of the fund's asset management business. Now the market has AliPay, TenPay, quick money, etc. seven third party payment companies through regulatory approval to obtain fund sales license and sale fund products directly. The rapid development of the fund based on the network platform of the third party payment, to a large extent affected the traditional banking income, thus cause a strong impact to the banking business.

Internet Monetary Fund swallowed bank deposits, raising the cost of bank financing. Treasure in the balance, for example, the public transferred their bank demand deposits to the balance of treasure, the balance of treasure in the collection of public funds after, in the form of the deposit agreement to lend money to banks, resulting in a significant increase in the cost of the bank's deposit taking, the profit space reduction. Although the bank also launched monetary fund, but at the same time also hurt their ownself.

\subsection{Interest Rate Liberalization and the Development of Deposit Insurance System}

\subsubsection{Interest Rate Liberalization}

The abolishment of deposit ratio monitoring indicators and the release of floating deposit rate ceiling, marking the domestic interest rate liberalization has been completed in form. But in the process of the "progressive", commercial banks felt the blast a "chill", such as deposit and loan spreads narrowed, interest rate risk, bank competition and other, and caused a lot of confusion and anxiety.

1) The interest rate liberalization shrink bank deposit and loan spreads

Under the control of the interest rate of deposit and loan spreads are generally higher than market deposit and loan spreads, which constitute the main source of profit for the commercial banks. But the restrictions on interest rates once liberalized, the market competition will make commercial banks to raise deposit rates in order to obtain funding sources and to reduce loan rates for obtain quality customers, thus the gap between the two has been shrinking, profit opportunities are also reduced accordingly [4]. For our country, the main source of profit for the commercial banks is the deposit and loan spreads, if deposit and loan spreads narrowed, their continued robust operation will be influenced.

2) The interest rate liberalization increase the volatility of the interest rate

Interest rate liberalization will increase the interest rate risk faced by commercial banks. Embodied in the interest rate market volatility caused by interest rate increases will boost the bank's interest rate uncertainty risk, yield curve risk and selective risk.

3) The interest rate liberalization intensify competition among banks 
Due to the business structure of commercial banks in China are generally similar and lack of its own unique business support, interest rate liberalization reform will trigger a fierce price war and narrow the spread between the deposit and loan rates which increased the competition between banks, especially small and medium banks.

\subsubsection{Deposit Insurance System}

Deposit insurance system that escorts the interest rate liberalization finally formally implemented in May 1, 2015. But it will bring about the increase of the cost of commercial banks and the differentiation between banks. Deposit insurance institutions charge a certain fee for commercial banks, will inevitably increase the cost of the bank in the short term. On the other hand, the state no longer reveal all the details after, the deposit insurance system implement differentiation rate, so the impact on each bank is not the same. The bank's operational capabilities, risk management capabilities and other differences will lead to further differentiation of its competitiveness.

\subsection{The Trend of Financial Mixed Operation Is Constantly Emerging}

The trend of financial mixed operation shows that the commercial banks in the future will be more policy support. But in the current environment, China's commercial banks have not yet built a mature model of financial holding companies, and the construction of financial companies can't be achieved overnight. Therefore, China's commercial banks are facing the challenges of the transformation of business management, how to better adapt to the trend of commercial banks will be worth deep thinking.

\section{The Development Trend of Commercial Bank Management under the Opportunities and Challenges}

The development of financial market is both opportunities and challenges for commercial banks. In the face of the financial impact of the Internet, commercial banks did not sit still. More and more commercial banks began to realize that in the Internet era, only by improving the understanding of new technology applications and conversion capabilities, can they grasp the market and customer needs and form user stickiness. Therefore, more and more commercial banks began to integrate resources, innovation, see the Internet as a useful supplement to the financial system. In terms of commercial banks, 2013 can be said to be a year that has the most innovative products since the reform and opening up. For example, in terms of financing, China Merchants Bank, Ping An Bank, Minsheng Bank all try to carry out in P2P financing. In terms of electricity suppliers, the major banks have set up their own B2B (B2C) e-commerce platform. Direct banking model began to rise, Minsheng Bank, Industrial bank and other banks have set foot in the field. Moreover, interest rate liberalization and the deposit insurance system development but also conducive to the promotion of the innovation of commercial banks, commercial banks must constantly diversified development, enrich its own services and products, thereby increasing income in order to cope with the cruel market competition. In the end, there is no doubt that the trend of mixed operation has brought more development space for the development of commercial banks. This article try to analyze the development trend of business management in the development of financial market from the following three aspects: commercial bank organizational structure, business model and business development.

\subsection{Commercial Bank Organizational Structure}

The core competence of commercial banks is the capacity of leading to the competitors, maintain sustainable development and competitive advantage, which is based on the long-term business practice experience and formed in the fierce market competition. In the face of financial markets various uncertain factors, commercial banks only to cultivate their own core competitiveness in order to remain invincible, and suitable organization structure is helpful to cultivate and enhance the core competitiveness of commercial banks. The concrete ways can be considered from the following aspects:

1) Improve the professional level of commercial bank management, reduce the cost of friction in the operation, implement the department management, give greater autonomy to the various departments, reduce the cost of coordination of various departments.

2) Implement the flat organization and management structure, reduce the organizational level, thereby reducing the cost of information delivery, labor costs and coordination costs and other operating costs. 
3) Separate power appropriately. On the form appropriate decentralized organizational structure, on the one hand to ensure the grass-roots to complete tasks timely, on the other hand help the junior staff can respond flexibly according to changes in the external environment.

4) Determine the appropriate level of management and management rang. On the one hand, the bank's internal management level can't be too much, the effective use of the traditional pyramid organizational structure is not conducive to the information transfer and resource, which is not conducive to the development and innovation of commercial banks. On the other hand, the internal management of commercial banks can't be too large. Due to the limited capacity of the management personnel, if the bank internal management span is too large, it will lead to waste of internal resources, efficiency loss.

5) Improve the professional division of labor within the commercial banks to prevent the occurrence and accumulation of all types of business risk.

6) Improve the standardization of key departments constantly, prevent the interference of human factors on the normal business activities of commercial banks, thereby reducing the risk.

7) Flexibility of organizational structure. Innovation is the process of new products and new service from scratch, often accompanied by iconoclastic, the commercial banks to development and cultivation of innovation ability, must establish a flexible organizational structure, to adapt to the changes in the internal and external environment.

\subsection{Business Model of Commercial Banks}

\subsubsection{Improve the "Customer Centered" Service Model of Commercial Banks}

Emphasis on interactive marketing, respecting for the customer experience, advocating open platform, etc., are the main features of the current Internet Banking, it emphasizes the mutual integration of traditional financial business and network technology. The direct interaction between the client and the terminal will be a great challenge to the traditional service mode of the bank. In the case of AliPay, AliPay company attaches great importance to the user experience, the door organization was founded a secondary user experience that used to actively try a variety of emerging technologies, to test the actual effect of its application to mobile payments, and to enhance the user experience of the parties as a main line in recent years. Internet financial companies are also walking in front of peers in providing flexible customized financial products for the general customers [5]. Such as the network of financial companies to provide customers with a fully meet the individual payment service solutions, and as long as enterprise customers put forward new mode of payment such as demand, third-party payment companies will soon give feedback appropriately. So in the user experience commercial banks also need to be more in-depth improvement.

\subsubsection{Innovate Commercial Banks Financial Services Model for Small and Micro Enterprises}

As early as 2004, when the Bank of China proposed the strategic transformation, the service business of the small and medium-sized enterprises has become the main direction of the transformation of the bank [6]. But the problem of financing of small and medium-sized enterprises is still not able to get a better solution. The main difficulty is there is no way for the traditional banking business model to spread risk according to the small and medium-sized enterprises' respective situation, which for the banks is a not small challenge. In sharp contrast, the network level of small and micro lending model has shown a very strong competitive. In the face of the challenges brought by the Internet banking, commercial banks should also pay attention to the opportunities. With the help of the Internet to reduce transaction costs and information costs, enhance the flexibility of the business, innovate financial services model for small and micro enterprises.

\subsubsection{To Speed up the Pace of Network Management}

In recent years, the major commercial banks have gradually expanded the investment in electronic banking, as of June 2012, the major banks of China's electronic channel trading replacement rate of more than 50\%, The China Merchants Bank, Minsheng Bank and Shanghai Pudong Development Bank alternative electronic channels trading rate reached more than $85 \%$ [7]. But only use Internet technology to move the line under the line, also not the true sense of the Internet Banking. In the development trend of Internet banking, the understanding of the network of commercial banks can't just stay in the channel instead, but to fully understand the idea and spirit of the Internet. The so-called Internet banking is not to simply move the general financial products to the 
network to sell so simple, but through the combination of network and financial characteristics of innovation.

\subsection{Business Development Trend of Commercial Banks}

At present, China's commercial banking business is mainly to deposit and loan, the main source of profit is still deposit and loan spreads. According to the Central Bank statistics, in 2015, 16 of the mainland listed banks around $70 \%$ of the profit from the deposit and loan spreads. However, in recent years, the commercial bank interest income is declining under the impact of the economic environment at home and abroad. In addition, China's commercial banks affected by the interest rate liberalization and the provision of pressure, according to NetEase Finance reported in May 18, 2016, the Shanghai and Shenzhen 16 commercial banks net profit growth in 2015 less than 6\%, the average growth rate of net profit of 5 large banks is only $0.79 \%$, but in 2014 the two numbers were $12 \%$ and $6.6 \%$, respectively. All these show that the commercial bank of our country in order to achieve their own survival and sustainable development had to change the deposit and loan spreads profit model, to find and develop new profit growth point. While from the practical experience of western commercial banks, low cost, low risk, high income intermediate business is the inevitable choice for commercial banks to achieve their own transformation. And through the annual report disclosed by the commercial banks in recent years can be seen intermediary business of commercial banks are rapidly developing business, however, there is a gap in the level of development compared with foreign countries. But on the other hand, it also shows that there is still a lot of room for development of commercial banks in China. This paper selected the Industrial and Commercial Bank of China, Bank of China, Shanghai Pudong Development Bank, Minsheng Bank, Nanjing Bank and Bank of Ningbo as the research object from the state-owned commercial banks, the joint-stock commercial banks and city commercial banks three types of commercial banks respectively, investigated its 2009-2015 intermediate business income and its share of operating income (as shown in Table 1), in terms of the proportion of business income in the intermediate business income, the average annual growth rate of the six banks were: $58.43 \%$, $129.71 \%, 165.43 \%, 339.86 \%, 78.71 \%, 143.86 \%$, the increasing proportion of commercial banks in China indicates that the intermediate business of commercial banks in our country is developing continuously, but the proportion is still relatively low, indicating that there is still much room for development and potential, commercial banks should vigorously strengthen the development of intermediary business.

In the development of intermediate business should pay attention to the following points:

1) Enhance the innovation ability of "product + marketing"

Commercial banks should adhere to the market oriented and customer-centric. On the one hand, integrate existing varieties of intermediary business, plan product, eliminate low benefit high cost business timely, assigned limited resources to reasonable product structure effectively. On the other hand, increase the intensity of financial product research and development and combined with their own advantages to develop innovative products suitable for different types of enterprises and residents' demand for new intermediate business varieties, and then improve the comprehensive, personalized financial services [8]. In marketing, first of all, the commercial banks should actively change the marketing concept, change the traditional customer triggered by the passive service into the bank triggered active marketing, improve service awareness and service quality. Secondly, commercial banks need to enrich the marketing methods. For example, in the current development of mobile Internet, they should actively take the road of community marketing, the use of high-quality social networking platform to introduce intermediate business products, strengthen the relationship between enterprises and customers. Finally, establish the overall marketing concept. On the one hand, strengthen the management of marketing activities to promote marketing integration, on the other hand, to further strengthen cooperation with the agent of the customer.

2) To enhance the layered service ability of "long tail business + loan business"

At present, the main business of the commercial banks is still deposit and loan business, and the intermediate business is more similar to the long tail business, it has great potential development. Loan business is a more popular business, the desired service is also more popular, while the intermediate business is more need to provide personalized service, through market segments and focus to distinguish the difference between the consumer to meet customer preferences, which committed to the personalized needs of most customers. An important feature of long tail products is that the amount of purchase needs to meet certain requirements. At present, an important reason for intermediate business has the low proportion of business income for commercial banks is that they have not accumulated to a certain amount. A hierarchical service will transfer their focus consciously 
Table 1. The development of intermediary business of some commercial banks in China in 2009-2015 (unit: 100 million yuan).

\begin{tabular}{|c|c|c|c|c|c|c|c|c|c|}
\hline \multirow{2}{*}{ Time } & \multicolumn{3}{|c|}{$\begin{array}{c}\text { Industrial and } \\
\text { Commercial Bank of China }\end{array}$} & \multicolumn{3}{|c|}{ Bank of China } & \multicolumn{3}{|c|}{ Shanghai Pudong Development Bank } \\
\hline & $\begin{array}{l}\text { Intermediate } \\
\text { business income }\end{array}$ & $\begin{array}{l}\text { Business } \\
\text { income }\end{array}$ & Proportion & $\begin{array}{l}\text { Intermediate } \\
\text { business income }\end{array}$ & $\begin{array}{l}\text { Business } \\
\text { income }\end{array}$ & Proportion & $\begin{array}{l}\text { Intermediate } \\
\text { business income }\end{array}$ & $\begin{array}{l}\text { Business } \\
\text { income }\end{array}$ & Proportion \\
\hline 2009 & 59,042 & 309,454 & $19.08 \%$ & 50,234 & 232,198 & $21.63 \%$ & 2720 & 36,824 & $7.39 \%$ \\
\hline 2010 & 78,008 & 380,821 & $20.48 \%$ & 59,214 & 276,817 & $21.39 \%$ & 4462 & 49,856 & $8.95 \%$ \\
\hline 2011 & 109,077 & 475,214 & $22.95 \%$ & 70,018 & 328,166 & $21.34 \%$ & 7205 & 67,918 & $10.61 \%$ \\
\hline 2012 & 115,881 & 536,945 & $21.58 \%$ & 75,198 & 366,091 & $29.81 \%$ & 9321 & 82,952 & $11.24 \%$ \\
\hline 2013 & 134,550 & 589,637 & $22.82 \%$ & 88,585 & 407,508 & $30.41 \%$ & 14,573 & 100,015 & $14.57 \%$ \\
\hline 2014 & 146,678 & 658,892 & $22.26 \%$ & 98,538 & 456,331 & $29.63 \%$ & 21,346 & 123,181 & $17.33 \%$ \\
\hline 2015 & 161,670 & 697,647 & $23.17 \%$ & 145,671 & 474,321 & $30.71 \%$ & 27,801 & 146,550 & $18.97 \%$ \\
\hline \multirow[b]{2}{*}{ Time } & \multicolumn{3}{|c|}{ Minsheng bank } & \multicolumn{3}{|c|}{ Bank of Nanjing } & \multicolumn{3}{|c|}{ Ningbo bank } \\
\hline & $\begin{array}{c}\text { Intermediate } \\
\text { business income }\end{array}$ & $\begin{array}{l}\text { Business } \\
\text { income }\end{array}$ & Proportion & $\begin{array}{c}\text { Intermediate } \\
\text { business income }\end{array}$ & $\begin{array}{l}\text { Business } \\
\text { income }\end{array}$ & Proportion & $\begin{array}{c}\text { Intermediate } \\
\text { business income }\end{array}$ & $\begin{array}{c}\text { Business } \\
\text { income }\end{array}$ & Proportion \\
\hline 2009 & 5006 & 42,060 & $11.90 \%$ & 346 & 3628 & $9.54 \%$ & 521 & 4176 & $12.48 \%$ \\
\hline 2010 & 8753 & 54,768 & $15.98 \%$ & 509 & 5306 & $9.59 \%$ & 597 & 5912 & $10.10 \%$ \\
\hline 2011 & 15,991 & 82,368 & $19.41 \%$ & 770 & 7463 & $10.32 \%$ & 850 & 7966 & $10.67 \%$ \\
\hline 2012 & 22,091 & 103,111 & $21.42 \%$ & 969 & 9115 & $10.63 \%$ & 1142 & 10,342 & $11.04 \%$ \\
\hline 2013 & 33,061 & 115,886 & $28.53 \%$ & 1242 & 10,478 & $11.85 \%$ & 1796 & 12,762 & $14.07 \%$ \\
\hline 2014 & 42,293 & 135,459 & $31.22 \%$ & 2078 & 15,992 & $12.99 \%$ & 2697 & 15,357 & $17.56 \%$ \\
\hline 2015 & 55,107 & 154,425 & $35.69 \%$ & 3436 & 22,830 & $15.05 \%$ & 4401 & 19,516 & $22.55 \%$ \\
\hline
\end{tabular}

Note: 1. Data source: the above commercial banks issued 2009-2015 annual statistical reports on the Stock Exchange. 2. Operating income in accordance with the "operating income $=$ net interest income + noninterest income" calculation.

from the fierce competition in the loan business to the long tail business and realize the accumulation of long tail business process quickly, so as to improve China's commercial banks intermediate business of the profit contribution rate and the level of development of their own.

3) Enhance the sustainable development ability of "talent + technology"

Whether it is product innovation or marketing, is the human activities ultimately, the talent is the guarantee of the sustainable development of intermediary business. So the bank to develop intermediary business should pay attention to personnel training, the implementation of a proactive strategy of talent. At the same time, we increase investment in science and technology, accelerate the progress of science and technology and industrial upgrading, and finally form the financial electronic system with the central content of electronic communications and computer. So that commercial banks can use high-quality talents with advanced technology to accelerate the pace of innovation of intermediate business and improve our products technology content and core competitiveness.

4) Enhance the ability of "risk prevention + risk control"

Commercial banks should strengthen the analysis and prediction of the risk of intermediary business, and develop a practical approach to prevent risks. Intermediary business has a wide variety, so it faces more risk points, commercial banks should be classified according to different categories of risk control, and develop appropriate measures to deal with the risk. Secondly, the loss of credit risk caused by the inability of the counterparty to perform the contract or the loss of performance, commercial banks can establish personal credit, business credit database, using bank information processing technology and database technology to develop credit risk management and corporate with finance advisory business to avoid credit risk. Moreover, they can use the credit rating system to provide services to avoid operational risks. In addition, in the face of increasingly prominent financial disintermediation, commercial banks should strengthen cooperation with insurance companies, securi- 
ties companies, fund companies and finance leasing companies, and actively carry out fund custody business, expand the third-party depository business field and scale.

\title{
3.4. Making Mixed Management Plan
}

Banks should count with their own actual situation as soon as possible to develop the bank's mixed business plan and plan the banks' mixed business strategy development blueprint. At present, a number of banks actively apply for a variety of pilot qualifications. They want to improve the management ability, risk management and control capabilities of mixed operation through the pilot, and then accumulate experience in mixed operation. In the future, we can further expand the scope and depth of mixed operation through a variety of ways, such as merger, acquisition, acquisition, and so on. According to the development and change of the environment of the securities market, regulatory policy would like to set up or buy securities firms so as to enter the security trading, direct investment can form or buy insurance company and then into trust services, direct financing business can form or to buy new financial futures company. At present, a number of banks in the various fields of mixed pilot strive to achieve a breakthrough in some areas and achieve the first mover advantage.

\section{References}

[1] Bai, J.Z. (2014) Study on the Financial Development of the Internet and Its Impact on China’s Commercial Banks. The Southwestern University of Finance and Economics, Chengdu.

[2] Ye, F.F. (2014) The Influence of the Development of Internet Banking on the Commercial Banks in China. Henan University, Kaifeng.

[3] Lei, H.G. (2014) Research on the Development of Intermediate Business of Commercial Banks in the Process of Interest Rate Liberalization. The Southwestern University of Finance and Economics, Chengdu.

[4] We, X. (2015) The Influence of Bank Deposit Insurance System on Commercial Banks. Shopping Mall Modernization, 15, 76-78.

[5] Yun, F.S. (2008) Research on the Development of Mixed Operation Strategy of Commercial Banks in China Based on SWOT Analysis. Fudan University, Shanghai.

[6] Zhang, Y.C. (2013) Discussion on the Transformation of the Business Model of China's Commercial Banks. Jilin University, Changchun.

[7] Chen, J.S. (2015) Research on the Transformation of Mixed Operation of Chinese Commercial Banks. East China Normal University, Shanghai.

[8] Qi, H.L. (2014) Study on the Impact of Financial Disintermediation on the Business Model of Commercial Banks in China. Capital University of Economics and Business, Beijing.

\section{Scientific Research Publishing}

\section{Submit or recommend next manuscript to SCIRP and we will provide best service for you:}

\author{
Accepting pre-submission inquiries through Email, Facebook, Linkedin, Twitter, etc \\ A wide selection of journals (inclusive of 9 subjects, more than 200 journals) \\ Providing a 24-hour high-quality service \\ User-friendly online submission system \\ Fair and swift peer-review system \\ Efficient typesetting and proofreading procedure \\ Display of the result of downloads and visits, as well as the number of cited articles \\ Maximum dissemination of your research work
}

Submit your manuscript at: http://papersubmission.scirp.org/ 